\title{
THE EFFECT OF MARKETING MIX ON CONSUMER SATISFACTION AND LOYALTY FOR INDONESIAN BRAND SALAD DRESSING "XYZ"
}

\author{
Christian Arianto Rahardjo*)1, Harianto**), and Heny K. Suwarsinah $\left.{ }^{* * *}\right)$ \\ *) PT Sensient Technologies Indonesia \\ Jl. Boulevard Artha Gading, Kelapa Gading, Jakarta 14240 \\ ${ }^{* *}$ Department of Agribusiness, Faculty of Economics and Management, IPB University \\ Jl. Agatis, IPB Dramaga Campus, Bogor 16680 \\ ${ }^{* * *}$ School of Business, IPB University \\ Jl. Raya Pajajaran, Bogor 16151
}

\begin{abstract}
XYZ', as a salad dressing product, can help consumers to prepare meals in a short time. In Indonesia, growth in salad dressing products every year is relatively high, increasing by $120 \%$ per year. The market share of salad dressings is also getting bigger with the addition of new players and variants. The purpose of this research was identifying the attributes affecting consumers' satisfactions and their satisfaction levels. The attributes used in this research were related to the marketing mix. Consumer loyalty is also important so that 'XYZ' can compete to fulfil consumer needs. This research used a quantitative descriptive method by conducting an online survey of 'XYZ' salad dressing consumers and direct interviews in shopping centers. The respondent criteria were females who were more than 18 years old and lived in Jabodetabek area. The technique of data processing and analysis used in this research was a quantitative descriptive analysis by using Structural Equation Modeling (SEM) and LISREL software version 8.7. Based on the results of research and evaluation on respondents, it can be concluded the marketing mix that has a significant effect on consumer satisfaction is product, price, and place. Promotion has no significant effect on consumer satisfaction. Consumer satisfaction has a significant effect on consumer loyalty. Suggestions to increase consumer satisfaction and loyalty to ' $\mathrm{XYZ}$ ' brand are to sell products that meet consumer tastes and to maintain the product quality. The placement of 'XYZ' product in the shopping center must be taken into account to make it easy to find and maintain its product availability in the market. This can increase consumer satisfaction and lead to an increase in consumer loyalty.
\end{abstract}

Keywords: consumer loyalty, consumer satisfaction, marketing mix, salad dressing, SEM

Abstrak: "XYZ" sebagai salah satu produk salad dressing, dapat membantu konsumen menyiapkan makanan dalam waktu singkat. Pertumbuhan produk salad dressing setiap tahun cukup tinggi yaitu meningkat $120 \%$ tiap tahun. Pangsa pasar salad dressing juga semakin besar dengan bertambahnya pemain baru dan varian baru. Tujuan dari penelitian ini adalah untuk mengetahui atribut yang mempengaruhi kepuasan dan bagaimana tingkat kepuasan konsumennya. Atribut yang diambil dalam penelitian ini terkait dengan bauran pemasaran. Penelitian menggunakan metode deskriptif kuantitatif dengan Teknik pengolahan dan analisis data pada penelitian ini adalah analisis deskriptif kuantitatif. Alat bantu analisis menggunakan Structural Equation Modelling (SEM) dan software LISREL versi 8.7. Hasil penelitian diperoleh kesimpulan bauran pemasaran yang berpengaruh signifikan terhadap kepuasan konsumen adalah variabel produk, harga, dan tempat. Sebaliknya variabel promosi memberikan pengaruh yang tidak signifikan terhadap kepuasan konsumen. Kepuasan konsumen berpengaruh signifikan terhadap loyalitas konsumen. Saran yang dapat diberikan untuk meningkatkan kepuasan dan loyalitas konsumen produk "XYZ" adalah dengan menjaga rasa produk agar sesuai dengan selera konsumen dan menjaga kualitas produk. Penempatan produk "XYZ" di pusat perbelanjaan juga harus diperhatikan agar selalu mudah ditemukan serta menjaga ketersediaan produk di pasaran. Hal tersebut dapat meningkatkan kepuasan konsumen dan berujung pada kenaikan loyalitas konsumen.

Kata kunci: bauran pemasaran, kepuasan konsumen, loyalitas konsumen, salad dressing, SEM

\footnotetext{
${ }^{1}$ Alamat Korespondensi:

Email: christianarianto6@gmail.com
} 


\section{INTRODUCTION}

Lifestyle and consumer needs in consuming food are changing. Changes could be affected by increasing population of the middle class in Indonesia $(37 \%$ in 2004 into $56.7 \%$ in 2013) that encourages the food industry to be able to diversify and develop its products into economical products and premium products. Eating healthy food is also a trend among educated consumers who have lived abroad or who have been exposed to foreign products through various media (Rangkuti and Wright, 2014). Based on data from the BPS (2017), it is estimated that around 80 million people or $34 \%$ of Indonesia's total population are millennials. Millennials (those currently aged 18-37 years) have different characteristics from previous generations due to the influence of technology and the speed of information in form of social networks, smartphones, and internet (Ali and Purwandi, 2016). The survey conducted by Bozarth et al. (2016) also shows that consumers, especially millennial, begin to realize a healthy lifestyle so they begin to reduce the consumption of ready-to-eat foods. In addition, more and more young women, who work in office, had less time to spent with family and less time to prepare dishes to eat with family (Schaner and Das, 2016 ). Looking at current conditions, consumers want food products that can be cooked easily, quickly, and instantaneously to adjust their busy schedules.

For food industry, those things are noteworthy. There are still few companies that have practical food products, easy to serve, have good taste and healthy nutrition. Consumers who are loyal to products that are still classified in niche market have an important role for the success of this product in the future. Sumarwan
(2015) explained that loyal consumers can recommend others to purchase certain products. Forms of consumer loyalty can be seen from various things, including awareness of a brand and consumer satisfaction. One of the food products included in this category is salad dressing. Based on market conditions in 2017, the growth for salad dressing products is quite high, which is an increase of $120 \%$ every year, in line with the increasing sales for "XYZ" products every year as seen in Figure 1. Compared to competitors, sales data for "XYZ" brand was less competitive. As seen in Figure 2, "XYZ" market share can't beat main competitor "M".

To increase sales of product, need strategies in sales and marketing process to win the competition. In managing marketing, companies must develop strategies for each element of the marketing mix that can be responded positively by consumers. That marketing mix is commonly referred to as $4 \mathrm{P}$, which consists of a price, place, product, and promotion. In addition to knowing the condition of product strength from the marketing mix, it is very important to know the level of consumer satisfaction and loyalty and see the attributes that influence it. This will be useful for developing the right marketing strategy that will be able to increase sales volume and product market share. The higher consumer loyalty to a product, the more difficult it is for consumers to switch to other products. Based on that, the problems that will be raised in this study include how is the influence of the marketing mix on consumer satisfaction of 'XYZ' salad dressing products and how is the relationship between consumer satisfaction and consumer loyalty for 'XYZ' salad dressing products.

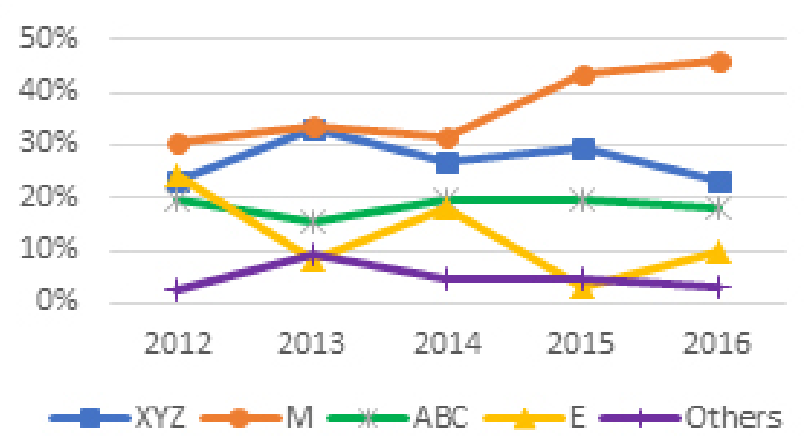

Figure 2. Market share of salad dressing in Indonesia

Figure 1. Sales of salad dressing in Indonesia

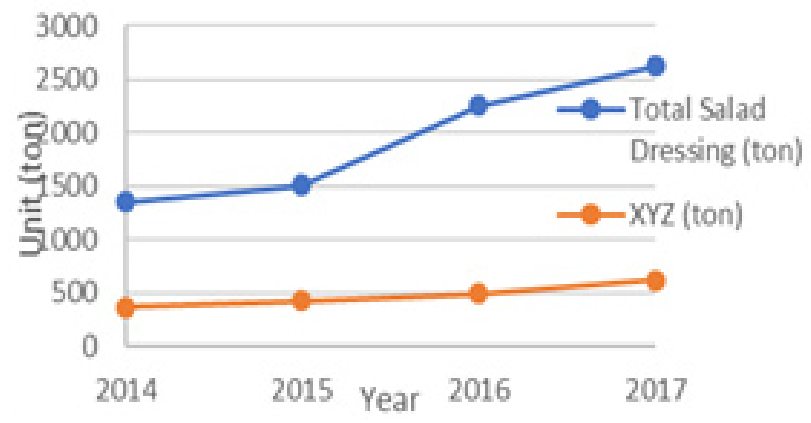


The research that will be carried out refers to theories related to the processed food industry, especially salad dressing products, marketing mix, consumer satisfaction, and consumer loyalty. Kosasih (2013) conducted a research related to the marketing mix that analyzes the effect of the marketing mix on the satisfaction and loyalty of consumers of Ampera restaurant in Jakarta. By using the SEM model, an analysis concluded that prices are the factor that most influences consumer satisfaction; while the places mix and employees do not have a significant influence on consumer satisfaction. Pavlina (2015) presents her study to find out which factors most influence consumer satisfaction when using public transportation in the city of Ostrava, Czech Republic. The SEM model used to analyze the factors related to consumer satisfaction shows that the logistics parameters that most influence consumer satisfaction. The research conducted by Iskandar et al. (2017) analyzes how the marketing mix of 7P influences the satisfaction and loyalty of honey consumers. By using SEM analysis method, the results show that the marketing mix that has the most significant influence on consumer satisfaction is physical facilities, location, products. In addition, consumer satisfaction has a significant influence in shaping consumer loyalty. Dimyati (2015) conducted a study which aims to determine the relationship between consumer satisfaction, switching costs, consumer retention of their trust in the Simpati brand. By using the SEM model, the results show that consumer satisfaction has a significant effect on consumer trust in the Simpati card. Suwarni and Mayasari (2009) conducted a study using a survey approach and purposive sampling. The data obtained were processed using linear regression analysis and there were significant effects on product quality and price on consumer satisfaction, product quality on consumer loyalty, and satisfaction with consumer loyalty. Anggraini et al. (2013) conducted a study entitled aimed to determine the level of satisfaction and loyalty of 'Gulaku' consumers. In addition, this study is also intended to analyze the effect of the marketing mix on 'Gulaku' consumer satisfaction and loyalty in Bandar Lampung City. By using the SEM analysis methods, the marketing mix does not significantly influence the level of satisfaction and loyalty of 'Gulaku' consumers in Bandar Lampung City. This is because the value received by consumers from the four marketing mix variables is not real/direct. Research related to the influence of the marketing mix on consumer loyalty has also been done by Selang (2013). The chosen marketing mix includes a mix of products, prices, places, and promotions that want to be known to influence consumer loyalty. By using multiple regression analysis, obtained results that product mix, price, promotion and place simultaneously have a significant effect on consumer loyalty. Partially only product mix and price have a significant effect on consumer loyalty. Fathimah (2013) conducted a study entitled by using descriptive analysis and multiple regression analysis. The results showed that product, price, place/distribution, and promotion variables simultaneously had no significant effect on consumer satisfaction, because the value of the coefficient of determination was low. Among the independent variables studied, the most influential variable is the price mix. Based on problem statements, this study aimed to achieve main objective, how does marketing mix (product, price, location, promotion) affect consumer satisfaction and how does consumer satisfaction affect consumer loyalty for 'XYZ' salad dressing products.

The scope for this research is limited to ' $\mathrm{XYZ}$ ' salad dressing products, conducted in the Greater Jakarta (Jabodetabek) area because the largest sales volume for consumer goods products is in this area, and study is carried out until the managerial implications stage, while the managerial implementation stage is submitted entirely to the management of 'XYZ' manufacturer.

\section{METHODS}

The study was carried out in the Jabodetabek area because this region has the largest sales volume for salad dressing products. Data collection is conducted from April 2018 to July 2018. Types and sources of data collected in this study are primary data and secondary data. Primary data in form of information gathered using questionnaire tools. Respondents were selected based on their availability to be interviewed and fulfill the requirements to be made respondents. Questionnaire are used online and face-to-face (personal interview) method for consumers of 'XYZ' salad dressings. For secondary data obtained from internal and external relevant companies such as statistical data, company profile data, salad dressing, and sales data, from journals or relevant research results.

Respondents taken were restricted to women over the age of 18 who had purchased and consumed ' $\mathrm{XYZ}$ ' salad dressing products in the past 6 months. In this study, the number of respondents taken was 172 people. Measurement scale used Likert scale with 5 
(five) points, that is 1 stated as strongly disagree and 5 stated as strongly agree. Tools used in this research are computers and Lisrel 8.72 software. Lisrel is one of alternative method of SEM (Structural Equation Modelling) which can be used to overcome problems in relationship. Exogenous latent variables in this research were product ( $\xi 1)$, place $(\xi 2)$, promotion ( $\xi 3)$, and price ( $\xi 4)$. Endogenous latent variables were satisfaction $(\eta 1)$ and loyalty $(\eta 2)$. Variables used in Table 1.

The marketing mix in this research uses the $4 \mathrm{P}$ principle, because the object under study is a food product so it is not suitable to use the 7P principle which is usually used in service products. Data from consumers then analyzed using the SEM method so that it can be seen which marketing mix affects consumer satisfaction. Consumer satisfaction is analyzed whether it affects consumer loyalty. SEM model can be seen in Figure 3.

From the SEM analysis that carried out in the previous stage, obtained weights, relationships, and the influence of each indicator variables and exogenous and endogenous latent variables. The next analysis that can be used to determine the level of consumer satisfaction is using Consumer Satisfaction Index (CSI). The calculation of the CSI is based on the weight of each marketing mix indicator. The weight is multiplied by the percentage of satisfied answers, in this case the top two boxes answer is the agreed answer (score 4) and strongly agrees (score 5) on the indicators that compile satisfaction. The method used to measure Consumer Loyalty Index (CLI) is almost the same as that used to measure consumer satisfaction. The difference is in the calculation of the loyalty index using endogenous latent variables, which is consumer loyalty. CSI and CLI criteria then divided into 5 categories, with each detail can be seen in Table 2.

Research related to the level of consumer loyalty for salad dressings is based on the image provided in Figure 4. Consumer needs for salad dressing products encourages the purchase of products. Market growth for salad dressing products continue to increase resulting in competition. The marketing mix strategy in this case uses the principle of $4 \mathrm{P}$, in accordance with the related object is a food product that is not in suitable with the principle of 7P, which is usually used in service products. Assessment is carried out by consumers and then implemented using the SEM method so that it can be known which marketing mix increases consumer satisfaction. Consumer satisfaction then analyzed whether it would increase consumer loyalty. Based on the results of this analysis, that could be used as a reference in making managerial implications that can be applied by XYZ manufacturer.

Based on previous research conducted by Fathimah (2013), Kosasih (2015), and Iskandar et al. (2017), can be formulated:

H1 : Product has a significant effect on consumer satisfaction

H2 : Place has a significant effect on consumer satisfaction

H3 : Promotion has a significant effect on consumer satisfaction

H4 : Price has a significant effect on consumer satisfaction

H5 : Consumer satisfaction has a significant effect on consumer loyalty

Table 1. Variables of research

\begin{tabular}{|c|c|}
\hline Exogenous latent variables & Code \\
\hline \multicolumn{2}{|l|}{ Product $(\xi 1)$} \\
\hline Product has desired taste & $\mathrm{X} 1$ \\
\hline Product has desired thickness & $\mathrm{X} 2$ \\
\hline Product has desired packaging and design & $\mathrm{X} 3$ \\
\hline Product has desired shelf life & $\mathrm{X} 4$ \\
\hline Product has desired quality & $\mathrm{X} 5$ \\
\hline Product helps to prepare healthy food & $\mathrm{X} 6$ \\
\hline \multicolumn{2}{|l|}{ Place $(\xi 2)$} \\
\hline Easy to find in market place & $\mathrm{X} 7$ \\
\hline Always available in market place & $\mathrm{X} 8$ \\
\hline Located in specific location in market place & $\mathrm{X} 9$ \\
\hline \multicolumn{2}{|l|}{ Promotion ( $\xi 3)$} \\
\hline Advertisement in medias & $\mathrm{X} 10$ \\
\hline Discount & $\mathrm{X} 11$ \\
\hline Free gimmick in specific purchase & $\mathrm{X} 12$ \\
\hline Free product in specific purchase & $\mathrm{X} 13$ \\
\hline Information banner in market place & $\mathrm{X} 14$ \\
\hline \multicolumn{2}{|l|}{ Price $(\xi 4)$} \\
\hline (Price according to product quality & $\mathrm{X} 15$ \\
\hline Price competes with other brands & $\mathrm{X} 16$ \\
\hline Price according to product quantity & $\mathrm{X} 17$ \\
\hline \multicolumn{2}{|l|}{ Endogenous latent variables } \\
\hline \multicolumn{2}{|l|}{ Consumer satisfaction $(\eta 1)$} \\
\hline Overall satisfaction & Y1 \\
\hline \multicolumn{2}{|l|}{ Consumer loyalty ( $\eta 2)$} \\
\hline Make purchase regularly & $\mathrm{Y} 2$ \\
\hline Not affected by other brands & Y3 \\
\hline Recommending the brand to others & Y4 \\
\hline
\end{tabular}




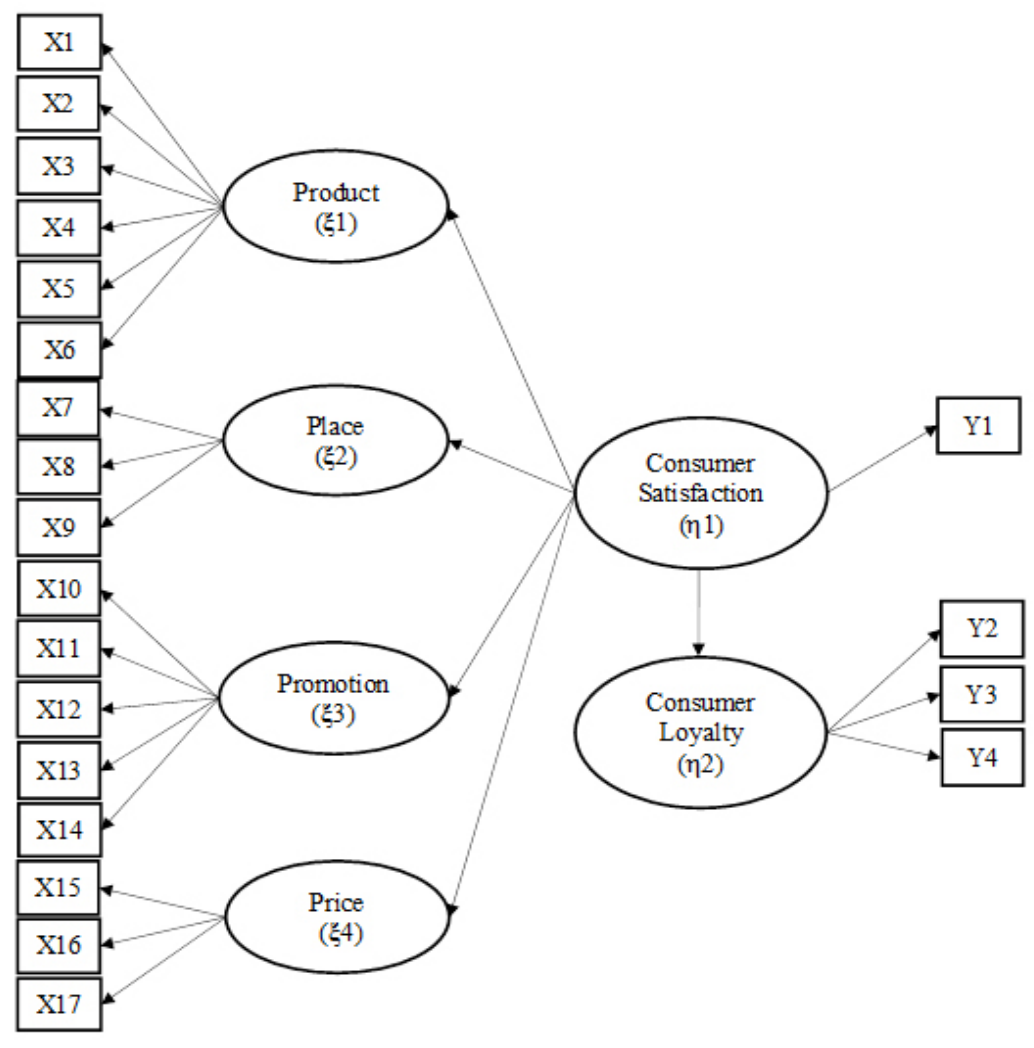

Figure 3. SEM Model

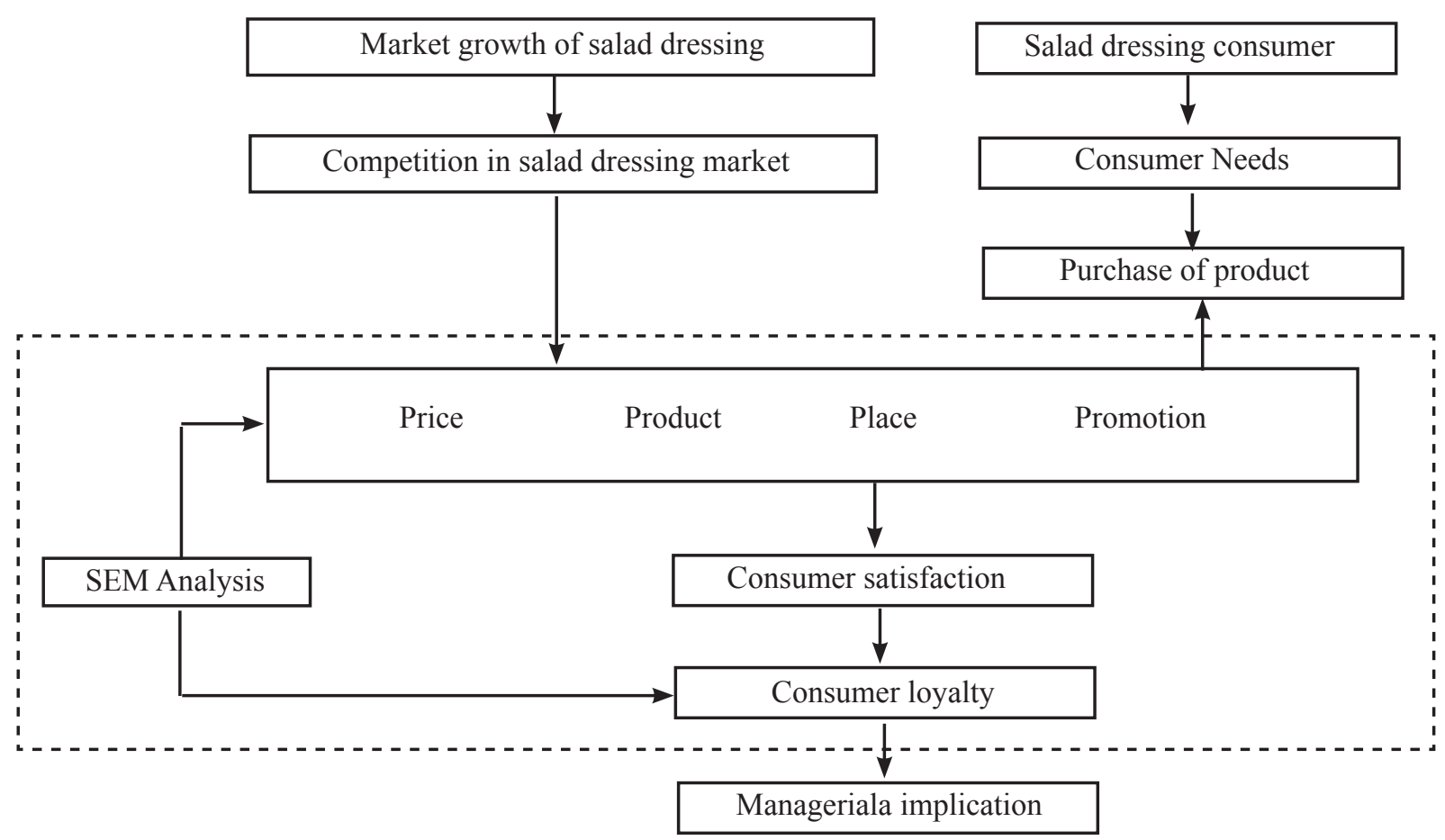

Figure 4. Research framework 
Table 2. CSI and CLI criteria

\begin{tabular}{llll}
\hline & CSI & \multicolumn{1}{c}{ CLI } \\
\hline \multicolumn{1}{c}{ Criteria } & \multicolumn{1}{c}{ Score } & \multicolumn{1}{c}{ Criteria } & \multicolumn{1}{c}{ Score } \\
\hline Very satisfied & $80,1<\mathrm{CSI}<100$ & Very loyal & $80,1<$ CLI $<100$ \\
Satisfied & $60,1<\mathrm{CSI}<80$ & Loyal & $60,1<$ CLI $<80$ \\
Neutral & $40,1<\mathrm{CSI}<60$ & Neutral & $40,1<$ CLI $<60$ \\
Not satisfied & $20,1<\mathrm{CSI}<40$ & Not loyal & $20,1<$ CLI $<40$ \\
Very not satisfied & CSI $<20$ & Very not loyal & CLI $<20$ \\
\hline
\end{tabular}

\section{RESULTS}

\section{Validity and Reliability}

Validity test is done using the number of respondents (n) as many as 30 people. R-table value for $\mathrm{n}=30$ is 0.361. All R-arithmetrics (correlation coefficients) obtained from the results of processing the research data are greater than R-tables. Reliability testing was performed using SPSS and resulted in a Cronbach Alpha value greater than 0.60. Ghozali (2006) states that if a construct or variable has a Cronbach Alpha value $>0.60$, then all indicators on the dimensions used in the study can be accepted.

\section{Respondent Demographic Profile}

The demographic profile used in this study includes gender, age range, domicile, last level of education, type of work, marital status, monthly income and expenditure. The most presentation results for the demographic profile of the respondents were all them are female, mostly already married, the highest age range at the age of 26-35 years, most of them were domiciled in Jakarta, the highest level of education was Bachelor (S1), the most type of work as private employees, with income per month in the range of IDR 1,000,000-IDR5,000,000 and monthly expenses in the range of IDR2,000,000-IDR4,000,000.

\section{Consumer Consumption Behavior of 'XYZ' Brand}

Data collection for ' $\mathrm{XYZ}$ ' consumer consumption behavior is done to better understand consumers so that the suggestions and decisions that will be taken can be formulated properly. The highest percentage results for consumption behavior of ' $\mathrm{XYZ}$ ' consumers in general are accustomed to using Original variants, sachet size of 100 grams, frequency of purchase every 1 month, location of purchases at supermarkets, choosing to use 'XYZ' because of its good quality, used as sauce for dipping, and using $\mathrm{M}$ competitors as an alternative salad dressing.

\section{Model Fit Criteria}

Based on the evaluation, the model built in this study has fulfilled the conformity test requirements. The results of the overall model suitability criteria can be seen in Table 3. GFI and AGFI values are still below the recommended acceptance threshold value $(>0.90)$, but both still meet the good model acceptance requirements suggested by Doll et al. (1994) and Baumgartner and Homburg (1996) which has a value of $>0.80$. From the seven model suitability indicators used, all have concluded good fit, it can be said that the model built is good.

\section{Lisrel Analysis - Outer Model Evaluation}

An indicator variable is said to be valid when it has standardize loading factor (SLF) greater than the tolerable loading factor limit, which is $>0.50$ and has a t-value above 1.96 (Hartono, 2008). Therefore, if each variable has a SLF value $>0.5$ then it can be said that this variable has a significant contribution to the formation of latent variables. Based on the loading factor and t-arithmetic obtained and can be seen in Table 4. T-value that cannot be seen in the $\mathrm{Y} 1$ variable towards the consumer satisfaction variable and the Y2 variable towards the consumer loyalty variable because the SEM model always assumes that the first indicator variable of each endogenous variable must be significant or valid. 
Table 3. Model fit criteria

\begin{tabular}{lccc}
\hline Goodness of Fit & Cut-off & Result & Means \\
\hline RMR (Root Mean Square Residual) & $<0.05$ or $<0.1$ & 0.044 & Good Fit \\
RMSEA (Root Mean Square Error) & $<0.08$ & 0.057 & Good Fit \\
GFI (Goodness of Fit) & $>0.90$ or $>0.80$ & 0.87 & Good Fit \\
AGFI (Adjusted Goodness of Fit Index) & $>0.90$ or $>0.80$ & 0.83 & Good Fit \\
CFI (Comparative Fit Index) & $>0.90$ & 0.98 & Good Fit \\
NFI (Normed Fit Index) & $>0.90$ & 0.95 & Good Fit \\
RFI (Relative Fit Index) & $>0.90$ & 0.93 & Good Fit \\
\hline
\end{tabular}

Table 4. Validity test for measurement model

\begin{tabular}{lcclcc}
\hline Relation & Loading Factor & T-value & Relation & Loading Factor & T-value \\
\hline $\mathrm{X} 1 \rightarrow$ Product $(\xi 1)$ & 0.68 & 9.53 & $\mathrm{X} 12 \rightarrow$ Promotion $(\xi 3)$ & 0.63 & 6.22 \\
$\mathrm{X} 2 \rightarrow$ Product $(\xi 1)$ & 0.60 & 8.22 & $\mathrm{X} 13 \rightarrow$ Promotion $(\xi 3)$ & 0.68 & 8.32 \\
$\mathrm{X} 3 \rightarrow$ Product $(\xi 1)$ & 0.54 & 7.22 & $\mathrm{X} 14 \rightarrow$ Promotion $(\xi 3)$ & 0.77 & 9.25 \\
$\mathrm{X} 4 \rightarrow$ Product $(\xi 1)$ & 0.64 & 8.83 & $\mathrm{X} 15 \rightarrow$ Price $(\xi 4)$ & 0.81 & 12.22 \\
$\mathrm{X} 5 \rightarrow$ Product $(\xi 1)$ & 0.81 & 12.25 & $\mathrm{X} 16 \rightarrow$ Price $(\xi 4)$ & 0.75 & 11.05 \\
$\mathrm{X} 6 \rightarrow$ Product $(\xi 1)$ & 0.55 & 7.34 & $\mathrm{X} 17 \rightarrow$ Price $(\xi 4)$ & 0.89 & 14.07 \\
$\mathrm{X} 7 \rightarrow$ Place $(\xi 2)$ & 0.70 & 9.33 & Y1 $\rightarrow$ Consumer Satisfaction $(\eta 1)$ & 0.97 & - \\
$\mathrm{X} 8 \rightarrow$ Place $(\xi 2)$ & 0.73 & 9.89 & Y2 $\rightarrow$ Consumer Loyalty $(\eta 2)$ & 0.84 & - \\
$\mathrm{X} 9 \rightarrow$ Place $(\xi 2)$ & 0.93 & 12.91 & Y3 $\rightarrow$ Consumer Loyalty $(\eta 2)$ & 0.72 & 9.65 \\
X10 $\rightarrow$ Promotion $(\xi 3)$ & 0.91 & 8.69 & Y4 $\rightarrow$ Consumer Loyalty $(\eta 2)$ & 0.57 & 7.97 \\
X11 $\rightarrow$ Promotion $(\xi 3)$ & 0.55 & 7.15 & & & \\
\hline
\end{tabular}

Note: loading factor score $>0.5$ and $t$-value $>1.96=$ valid

\section{Factors that Influence Consumer Satisfaction and Loyalty}

The results of testing hypotheses for structural models can be seen in Table 5. The significance level of each relationship between latent variables and t-arithmetic must be greater than $\mathrm{t}$-table for significance. There are three variables that have a significant influence on consumer satisfaction, namely product, place and price. Whereas for the promotion dimension has a t-value below 1.96 and it is negative which indicates that dimension gives a decrease in consumer satisfaction but not significant.

SEM model used latent variable from marketing mix. As can be seen in Table 5, latent variables from marketing mix that affect consumer satisfaction. From the data obtained shows that product variables have significant results on consumer satisfaction. This result is consistent with Deswindi (2007), Haryanto (2013), and Sembiring et al. (2014) which states that product variables have a significant effect on consumer satisfaction. The results of the study also show the relationship between place variables and consumer satisfaction has a significant value. This is in line with the research conducted by Kosasih (2013) and Iskandar et al. (2017) which states that place variables have a significant effect on consumer satisfaction. Promotion variables become variables that are not significant and tend to be negative. This is in line with the research conducted by Anggraini (2013) and Garg et al. (2016) which states that promotion does not have a significant direct effect on consumer satisfaction. Based on the results of the analysis, the relationship between price and consumer satisfaction has significant results. This is in line with the research conducted by Fathimah (2013), Astuti et al. (2015), and Verma and Singh (2017) which state that one of the factors that influence consumer satisfaction is the price factor that fits the desires of consumers and has a significant influence.

From the tests that have been done, it is known that consumer satisfaction can influence consumer loyalty. This is based on the value of the construct coefficient of the endogenous latent variable satisfaction with the endogenous latent variable of loyalty of 0.97 . The value generated by the variable satisfaction with loyalty is consistent with several previous studies conducted by Espejel et al. (2008), Rahmawati et al. (2013), Sujatha and Chandrika (2013), and Setyadi (2017), where consumer satisfaction has a positive and significant influence on consumer loyalty. 
Table 5. Hypothesis testing result

\begin{tabular}{lccc}
\hline Latent Variable & Construct Coefficient & T-value & Conclusion \\
\hline Product $\rightarrow$ Consumer Satisfaction & 0.51 & 4.20 & Accept H1 \\
Place $\rightarrow$ Consumer Satisfaction & 0.19 & 2.48 & Accept H2 \\
Promotion $\rightarrow$ Consumer Satisfaction & -0.07 & -1.11 & Reject H3 \\
Price $\rightarrow$ Consumer Satisfaction & 0.28 & 2.50 & Accept H4 \\
Consumer Satisfaction $\rightarrow$ Consumer Loyalty & 0.97 & 14.59 & Accept H5 \\
\hline
\end{tabular}

Note: T-value $>1.96=$ accept hypothesis

\section{Consumer Satisfaction Index (CSI)}

As can be seen in Table 6, the total calculations of XYZ consumer satisfaction index value was $83.21 \%$. When referring to consumer satisfaction criteria, these values fall into the category of very satisfied. In addition, the value of consumer satisfaction can be seen from each of the constituent indicator variables. From the product dimensions, consumers feel most satisfied with a good indicator of product quality. From the dimensions of the place, consumers feel most satisfied with the specific product location indicators in the shopping place. From the dimensions of promotion, consumers feel most satisfied with the indicator of the use of advertising as a promotional medium. From the price dimension, consumers feel most satisfied with the indicator of price suitability with the content/quantity of the product.

\section{Consumer Loyalty Index (CLI)}

Based on Table 6, the 'XYZ' consumer loyalty index is $75.11 \%$. When referring to consumer loyalty criteria, these values fall into the category of loyal. The level of consumer loyalty has a lower value compared to the level of consumer satisfaction. This can be caused because 'XYZ' products are food products that are easily substituted with other competitors. As obtained in 'XYZ's consumer behavior, many also use competitor products $(\mathrm{M})$. These results indicate that consumers can move to other brands if consumers feel ' $\mathrm{XYZ}$ ' cannot meet their needs, in terms of product characteristics and in terms of availability on the market.

\section{Managerial Implications}

The influence of the marketing mix on consumer satisfaction and loyalty can be used as material for evaluating company policies in marketing their products. From the results of the analysis that has been carried out, the company obtained an overview of what factors play a role in shaping the satisfaction and loyalty of consumers of 'XYZ' salad dressing products. From the model that has been made, the factor that most significantly influences consumer satisfaction is the product factor, followed by the place factor, and finally the price factor.

The main priority for company is the product factor. This is because this factor has the highest influence in providing consumer satisfaction. The product dimension consists of six indicators, which based on the calculation of the consumer satisfaction index, good product quality has the highest value followed by the product has a good taste according to consumer tastes. Product quality must be maintained by using quality materials and good manufacturing process. In this case, company should maintain the quality of its products while still implementing quality assurance system ISO:9001 and ISO:22000 for food security. With addition of halal certification from LPPOM MUI, making consumers feel safe about the quality of ' $\mathrm{XYZ}$ ' products. In addition, consumers choose 'XYZ' products compared to other products due to the taste and viscosity of product, which is in accordance with the tastes and desires of the respondents. According to Andersen and Hyldig (2015), consumer satisfaction for food products occurs before and after consuming the product. Consumer expectations of product taste and viscosity influence satisfaction that arise after consuming are strongly influenced by sensory experience. Therefore, it is very important to continue to develop feelings in accordance with the wishes of consumers. This is in line with the research conducted by Ferrinadewi (2005), where by differentiating products according to consumer expectations, it will increase consumer satisfaction. In this case, it is necessary to conduct a continuous survey and development of the taste so that the product remains favored by consumers. Also, company can launch new flavors that are preferred by consumers by doing some developments. 
The next priority is the price factor that has a significant influence on consumer satisfaction. The price dimension consists of three indicators, which based on the calculation of the consumer satisfaction index, the price matches to the content of the product has the highest value. It can be seen here that consumers who are mostly middle to lower class people pay close attention to prices with the content and quality of products, and compare them to competitors. In this case, company must be careful if they want to raise prices. The factor that must be considered is that 'XYZ"s selling price may not be higher than competitors with the same product content, or using the going-rate pricing strategy. This can be anticipated by conducting costeffective in production processes so production costs not too high, resulting in a not too high selling price, just as the results of research conducted by Astuti et al. (2015). Decision to distinguish the price of large packaging cheaper is also fairly precise.

The next priority is a place factor that has a significant influence on consumer satisfaction. The place dimension consists of three indicators, where based on the calculation of the consumer satisfaction index, the location of a specific product in a shopping place has the highest value. Judging from 'XYZ"s consumer behavior, which is most respondent make purchases at supermarkets, company can collaborate with supermarkets to position products in locations that match product categories, in line with research conducted by Kurniawan et al. (2016).

Table 6. CSI Calculation

\begin{tabular}{|c|c|c|c|c|c|c|}
\hline Indicator & Loading factor & Construct Coefficient & Influence & Weight & Top-two box (\%) & CSI Indicator $(\%)$ \\
\hline \multicolumn{7}{|l|}{ Product } \\
\hline $\mathrm{X} 1$ & 0.68 & 0.51 & 0.35 & 0.12 & 82.56 & 10.10 \\
\hline $\mathrm{X} 2$ & 0.60 & 0.51 & 0.31 & 0.11 & 83.14 & 8.97 \\
\hline $\mathrm{X} 3$ & 0.54 & 0.51 & 0.28 & 0.10 & 79.65 & 7.74 \\
\hline $\mathrm{X} 4$ & 0.64 & 0.51 & 0.33 & 0.12 & 80.23 & 9.24 \\
\hline $\mathrm{X} 5$ & 0.81 & 0.51 & 0.41 & 0.15 & 80.23 & 11.69 \\
\hline X6 & 0.55 & 0.51 & 0.28 & 0.10 & 67.44 & 6.67 \\
\hline \multicolumn{7}{|l|}{ Place } \\
\hline $\mathrm{X} 7$ & 0.70 & 0.19 & 0.13 & 0.05 & 88.95 & 4.17 \\
\hline $\mathrm{X} 8$ & 0.73 & 0.19 & 0.14 & 0.05 & 88.37 & 4.32 \\
\hline X9 & 0.93 & 0.19 & 0.18 & 0.06 & 83.14 & 5.18 \\
\hline \multicolumn{7}{|c|}{ Promotion } \\
\hline $\mathrm{X} 10$ & 0.91 & -0.07 & -0.06 & -0.022 & 53.49 & -1.20 \\
\hline $\mathrm{X} 11$ & 0.55 & -0.07 & -0.04 & -0.014 & 45.35 & -0.62 \\
\hline X12 & 0.63 & -0.07 & -0.04 & -0.016 & 62.21 & -0.97 \\
\hline $\mathrm{X} 13$ & 0.68 & -0.07 & -0.05 & -0.017 & 58.72 & -0.99 \\
\hline X14 & 0.77 & -0.07 & -0.05 & -0.019 & 48.84 & -0.93 \\
\hline \multicolumn{7}{|l|}{ Price } \\
\hline X15 & 0.81 & 0.28 & 0.23 & 0.080 & 88.37 & 7.07 \\
\hline $\mathrm{X} 16$ & 0.75 & 0.28 & 0.21 & 0.074 & 72.67 & 5.38 \\
\hline $\mathrm{X} 17$ & 0.89 & 0.28 & 0.25 & 0.088 & 83.72 & 7.36 \\
\hline Total & & & 2.83 & & & \\
\hline CSI (\%) & & & & & & 83.21 \\
\hline
\end{tabular}

Table 7. CLI Calculation

\begin{tabular}{lcccccc}
\hline Indicator & Loading factor & Construct Coefficient & Influence & Weight & Top-two box (\%) & CSI Indicator (\%) \\
\hline Y2 & 0.84 & 0.47 & 0.39 & 0.38 & 87.79 & 33.50 \\
Y3 & 0.72 & 0.58 & 0.42 & 0.40 & 66.28 & 26.75 \\
Y4 & 0.57 & 0.39 & 0.22 & 0.21 & 69.19 & 14.86 \\
\hline CLI (\%) & & & & & 75.11 \\
\hline
\end{tabular}




\section{CONCLUSIONS AND RECOMMENDATIONS}

\section{Conclusions}

Factors of the marketing mix that have a positive and significant influence on consumer satisfaction are the dimensions of the product, price, and place. For the promotion dimension it has no significant influence on consumer satisfaction. Consumer satisfaction has a significant influence on the consumer loyalty for ' $\mathrm{XYZ}$ ' salad dressing. Consumer satisfaction index is in very satisfied category; meanwhile consumer loyalty index is in loyal category.

\section{Recommendations}

The management of 'XYZ' manufacturer should pay special attention to the quality and taste of products because these two factors have a significant and highest influence on consumer satisfaction. For further research, could include effect switching behavior between ' $\mathrm{XYZ}$ ' and ' $\mathrm{M}$ ' salad dressing, other factors affecting consumer satisfaction and loyalty beside from marketing mix, and use bigger area of sampling such as all area in Indonesia.

\section{REFERENCES}

Ali H, Purwandi L. 2016. Indonesia 2020: The urban middle-class millenials. https://www. researchgate.net/publication/314448735 Indonesia_2020_The_Urban_Middle_Class_ Millenials [2018 January 2].

Andersen BV, Hyldig G. 2015. Consumer's view on determinants to food satisfaction, a qualitative approach. Appetite 95(2015):9-16. https://doi. org/10.1016/j.appet.2015.06.011.

Anggraini V, Prasmatiwi FE, Santoso H. 2013. Tingkat kepuasan dan loyalitas konsumen gulaku di Kota Bandar Lampung. Jurnal Ilmu-Ilmu Agribisnis 1(2): 149-155.

Astuti R, Silalahi RLR, Wijaya GDP. 2015. Marketing strategy based on marketing mix influence on purchasing decisions of Malang apples consumers at Giant Olympic Garden Mall (MOG), Malang City, East Java Province, Indonesia. Agriculture and Agricultural Science Procedia 3(2015): 67-71. https://doi. org/10.1016/j.aaspro.2015.01.015.

Baumgartner H, Homburg C. 1996. Applications of structural equation modeling in marketing and consumer research: a review. International Journal of Research in Marketing 13(2): 139-161. https://doi.org/10.1016/0167-8116(95)00038-0.

Bozarth L, Hasse L, Henning H, Kohrs C, Taylor C, Yeakle H. 2016. Newman's own research and consumer insights.https://slideshare. net/LaurenHasse/newmans-own-qualitativeresearch-and-consumer-insights[2017November 22].

[BPOM] Badan Pengawas Obat dan Makanan. 2016. Peraturan Kepala Badan Pengawas Obat dan Makanan Republik Indonesia Nomor 21 tahun 2016 tentang Kategori Pangan. https://standarpangan.pom.go.id/dokumen/ peraturan/2016/PerKa_BPOM_No_21_ Tahun_2016_tentang_Kategori_Pangan.pdf [2017 November 22].

[BPS] Badan Pusat Statistik. 2017. https://www. bps.go.id/ [2017 November 22]. https://doi. org/10.1007/JHEP03(2017)087.

Deswindi L. 2007. Kecepatan tingkat penerimaan dan perilaku konsumen terhadap produk lama yang mengalami perubahan dan produk inovasi baru dalam upaya memasuki dan merebut pasar. Business and Management Journal Bunda Mulia 53(2): 801-807.

Dimyati M. 2015. Consumer satisfaction and switching cost toward trust in the brand and consumer retention of Simpati in Jember. Journal of Arts, Science \& Commerce 6(2):15-26.

Doll WJ, Xia W, Torkzadeh G. 1994. A confirmatory factor analysis of the end-user computing satisfaction instrument. MIS Quarterly 18(4): 453-461. https://doi.org/10.2307/249524.

Espejel J, Fandos C, Flavian C. 2008. A key factor of consumer loyalty and buying intention of a PDO food product. British Food Journal 110(9):865-881. https://doi. org/10.1108/00070700810900585.

Fathimah F. 2013. Pengaruh bauran pemasaran terhadap kepuasan konsumen air mineral ASA di Samarinda. eJournal Ilmu Administrasi Bisnis 1(4):340-350.

Ferrinadewi E. 2005. Atribut produk yang dipertimbangkan dalam pembelian kosmetik dan pengaruhnya pada kepuasan konsumen di Surabaya. Jurnal Manajemen \& Kewirausahaan 7(2): 139-151.

Garg SA, Singh H, De KK. 2016. Direct and indirect effects of marketing mix elements on satisfaction. 
Academy of Marketing Studies Journal 20(1):5365.

Ghozali I. 2006. Aplikasi Analisis Multivariate dengan SPSS, Cetakan Ke-4. Semarang: Badan Penerbit Universitas Diponegoro.

Haryanto RA. 2013. Strategi promosi, kualitas produk, kualitas layanan terhadap kepuasan pelanggan pada restoran McDonald's, Manado. EMBA 1(4):1465-1473.

Iskandar AYS, Nurmalina R, Syuaib MF. 2017. The impacts of marketing mix on customer satisfaction and loyalty in honey product. International Journal of Science and Research (IJSR)2(7):1778-1783.https://doi.org/10.21275/ ART20175276.

Kosasih NN. 2013. Analisis pengaruh bauran pemasaran terhadap kepuasan dan loyalitas pelanggan Warung Nasi Ampera di Jakarta [tesis]. Bogor: Institut Pertanian Bogor.

Kurniawan H, Satria A, Suprayitno G. 2016. Perancangan strategi bauran pemasaran untuk meningkatkan kepuasan dan loyalitas nasabah pembiayaan umrah. Jurnal Aplikasi Bisnis dan Manajemen 2(1):32-42.

Pavlina P. 2015. The factors influencing satisfaction with public city transport: a structural equation modelling approach. Journal of Competitiveness 7(4):18-32.https://doi.org/10.7441/ joc.2015.04.02.

Rahmawati M. 2013. Analisis ekuitas merek minuman jus dalam kemasan botol Minute Maid di Kota Bogor [tesis]. Bogor: Institut Pertanian Bogor.

Rangkuti FY dan Wright T. 2014. Global agricultural processing network: indonesia food processing ingredients. [working paper]. USDA.
Schaner S, Das S. 2016. Female labor force participation in Asia: indonesia country study. Asian Development Bank. No 474. https://doi. org/10.2139/ssrn. 2737842.

Selang CAD. 2013. Bauran pemasaran (marketing mix) pengaruhnya terhadap loyalitas konsumen pada Fresh Mart Bahu Mall Manado. EMBA 1(3):71-80

Sembiring IJ, Suharyono, Kusumawati A. 2014. Pengaruh kualitas produk dan kualitas pelayanan terhadap kepuasan pelanggan dalam membentuk loyalitas pelanggan, studi pada pelanggan McDonald's MT Haryono Malang. Jurnal Administrasi Bisnis 15(1):1-10

Setyadi F. 2017. Analisis pengaruh persepsi nilai dan kualitas layanan terhadap kepuasan dan loyalitas konsumen Whynot Coffee Bogor [tesis]. Bogor: Institut Pertanian Bogor

Sumarwan U. 2015. Perilaku Konsumen: Teori dan Penerapannya dalam Pemasaran, Cetakan ke-3. Bogor: Ghalia Indonesia.

Sujatha P, Chandrika N. 2013. Switching costs, consumer satisfaction and brand loyalty: an empirical study on airtel cellular services in Chittor district. SUMEDHA Journal of Management 2(4): 83-95.

Suwarni, Mayasari SD. 2009. Pengaruh kualitas produk dan harga terhadap loyalitas melalui kepuasan konsumen. Jurnal Ekonomi Bisnis16(1):76-84.

Verma Y, Singh MRP. 2017. Marketing mix, consumer satisfaction and loyalty: an empirical study of telecom sector in Bhutan. Indian Journal of Commerce \& Management Studies 8(2): 121129. https://doi.org/10.18843/ijcms/v8i2/17. 